\title{
Research Note: Effect of tidal inundation on some chemical properties of soil of the Sundarbans (India)
}

\author{
Tanumi Kumar and Monoranjan Ghose \\ Agricultural and Ecological Research Unit, Indian Statistical Institute, 203 B.T. \\ Road, Kolkata - 700 108, West Bengal, India
}

\begin{abstract}
Soil samples from twenty seven sites of Indian Sundarbans were analysed for some chemical parameters. These sites were divided into three inundation types namely, diurnal, usual springtide and summer springtide. The study demonstrated that most of the soil properties significantly varied with inundation type. Sites inundated by usual springtides exhibited lowest concentrations of $\mathrm{pH}$, salinity ( $\mathrm{Sal})$, available phosphorus $(\mathrm{P})$, and exchangeable potassium $(\mathrm{K})$, sodium $(\mathrm{Na})$ and magnesium $(\mathrm{Mg})$, whereas summer springtide inundated sites had the highest concentrations of Sal, organic carbon (OC), available nitrogen $(\mathrm{N}), \mathrm{Na}, \mathrm{K}$ and $\mathrm{Mg}$. Highest level of $\mathrm{P}$ and lowest $\mathrm{N}$ in the diurnally inundated sites could be attributed to increased mobility of phosphates and denitrification or volatilization losses of inorganic nitrogen in the soils respectively. Highest concentration of $\mathrm{N}$ in summer springtide inundated sites could be attributed to increased ammonium ion mobility in the soils.
\end{abstract}

Keywords: Indian Sundarbans, tidal inundation, soil parameters, relationship.

Correspondence: T. Kumar Address: Agricultural and Ecological Research Unit. Indian Statistical Institute, 203 B.T. Road, Kolkata - 700 108, West Bengal, India. E-mail: tanumikumar@yahoo.co.in. Tel. No. $+(91)(033) 25753225$

DOI: $10.32945 /$ atr2929.2007 


\section{INTRODUCTION}

There are many environmental factors that can affect primary production and plant-species distribution in intertidal ecosystems; of these, the substrate characteristics are possibly the most important. However, the type of soil and its physical and chemical state are in turn affected by factors such as topography, tidal regimes, riverine sedimentation patterns, climate, tidal range and longterm sea-level changes (Boto, 1984)

Mangrove is a type of coastal woody vegetation that fringes muddy saline shores and estuaries in tropical and subtropical regions (Naskar and Guha Bakshi, 1987). On the Gangetic and Brahmaputra deltas of West Bengal and Bangladesh, lies the world's second largest mangrove forests, the Sundarbans (Ghose, 2001). According to satellite imagery of the Forest Survey of India (1999) total area of the Indian Sundarbans was 2125 kilometer square including 54 conglomerate islands, and excluding the anastomosing network of creeks and backwaters. The creeks and backwaters of the Sundarbans are subjected to tidal influence and are therefore saline. The tidal amplitude throughout the Sundarbans ranges from $3 \mathrm{~m}-5 \mathrm{~m}$ depending upon the solar phase and sometimes rises to $8 \mathrm{~m}$ during summer springtides (Mandal, 2003). Sites here are variously inundated. The inundation can be broadly divided into three types/classes based on the height reached by the tidal waves above the datum line and the frequency of flooding per month (Watson, 1928) - diurnal, usual springtide and summer springtide inundation (Table 1).

Acquisition of physical and chemical data on soil is required for the treatment of the diverse problems of mangrove ecology, such as salinity, inundation and nutrient acquisition (Snedaker, 1982). The relationship between tidal factors and accompanying soil attributes remain largely unexplored for the Indian Sundarbans. Hence in the present investigation the effects of tidal inundation on soil parameters have been analysed for some areas of Indian Sundarbans. 
Table 1. Inundation classes, respective height of tides above the datum line and frequency of flooding per month

\begin{tabular}{lcc}
\hline $\begin{array}{l}\text { Tidal inundation } \\
\text { class/type }\end{array}$ & $\begin{array}{l}\text { Height above } \\
\text { datum line }(\mathrm{ft})\end{array}$ & $\begin{array}{c}\text { Times flooded } \\
\text { /month }\end{array}$ \\
\hline Diurnal inundation & $0-13$ & $56-62$ \\
Usual springtide inundation & $13-15$ & $2-20$ \\
Summer springtide inundation & 15 -above & $0-2$ \\
\hline
\end{tabular}

\section{MATERIALS AND METHODS}

\section{Study sites}

Twenty seven sampling sites were selected from six different areas (including two islands) in the Sundarbans of West Bengal (Figure 1). Each sampling site is equivalent to a quadrate of size $4 \mathrm{~m} \times 16 \mathrm{~m}$. The latitude-longitude values of the study sites are presented in the Table 2 . Sites were broadly divided into three inundation types (Watson, 1928) viz. diurnally inundated sites (Diurnal) - ten, sites inundated by usual springtides (Usp) - nine and sites inundated by only summer springtides (Ssp) - eight.

\section{Soil sampling}

Soil sampling was done during the months of December, January and February of the years 2004-2006. Soil samples were collected in sterile polythene bags using metal sheet soil sampler $(10 \mathrm{~cm}$ diameter and $30 \mathrm{~cm}$ height) at a depth of $0-30 \mathrm{~cm}$ from 15 random locations in each sampling site. The samples were collected from the rhizospheres of the plants and from bulk soil and finally mixed to get a homogenous mixture of soil for each site.

\section{Determination of soil characters}

Soil $\mathrm{pH}$ and electrical conductivity were determined at 1:2.5 and 1:5 soil:water suspensions respectively according to Jackson (1973). Salinity (Sal) was calculated from electrical conductivity (Jackson, 1973). Potassium 


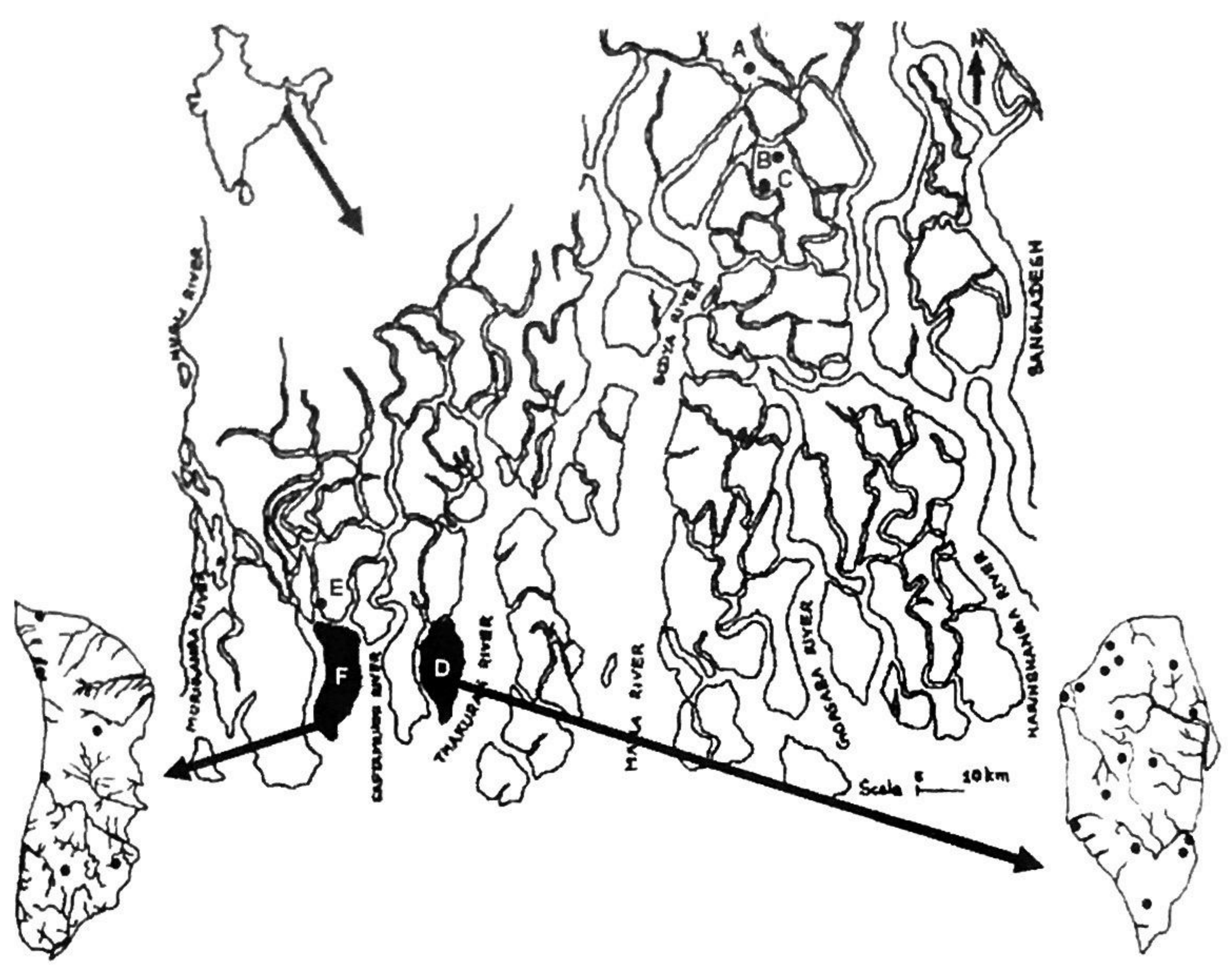

Figure 1. Map showing study areas. A Manmathanagar, B Sajnekhali, C Sudhanyakhali, $\mathrm{D}$ Dhanchi island, $\mathrm{E}$ Bhagwatpur and $\mathrm{F}$ Lothian island. Black dots indicate the study sites. 
Table 2. Study areas, number of sites studied at each area and their geographic locations

\begin{tabular}{|c|c|c|}
\hline Areas & Number of sites studied & Location of the sites \\
\hline Bhagwatpur & 1 & $21^{\circ} 44^{\prime} 33^{\circ} \mathrm{N} \& 88^{\circ} 18^{\prime} 29^{\prime \prime} \mathrm{E}$ \\
\hline Dhanchi (island) & 16 & $\begin{array}{l}21^{\circ} 41^{\prime} 23^{\circ} \mathrm{N} \& 88^{\circ} 25^{\prime} 28^{\prime \prime} \mathrm{E} \\
21^{\circ} 36^{\circ} 54^{\prime} \mathrm{N} \& 88^{\circ} 25^{\prime} 27^{\prime \prime} \mathrm{E} \\
21^{\circ} 41^{\prime} 41^{\prime} \mathrm{N} \& 88^{\circ} 26^{\circ} 00^{\prime \prime} \mathrm{E} \\
21^{\circ} 40^{\prime} 13^{\prime} \mathrm{N} \& 88^{\circ} 26^{\circ} 17^{\prime \prime} \mathrm{E} \\
21^{\circ} 41^{\prime} 51^{\prime} \mathrm{N} \& 88^{\circ} 26^{\prime} 15^{\prime \prime} \mathrm{E} \\
21^{\circ} 40^{\prime} 54^{\prime} \mathrm{N} \& 88^{\circ} 24^{\prime} 49^{\prime \prime} \mathrm{E} \mathrm{E} \\
21^{\circ} 40^{\prime} 21^{\prime} \mathrm{N} \& 88^{\circ} 25^{\prime} 53^{\prime \prime} \mathrm{E} \\
21^{\circ} 39^{\prime} 38^{\prime} \mathrm{N} \& 88^{\circ} 25^{\prime} 58^{\prime \prime} \mathrm{E} \\
21^{\circ} 41^{\prime} 16^{\prime} \mathrm{N} \& 88^{\circ} 25^{\prime} 10^{\prime \prime} \mathrm{E} \\
21^{\circ} 41^{\prime} 44^{\prime} \mathrm{N} \& 88^{\circ} 26^{\circ} 06^{\prime \prime} \mathrm{E} \\
21^{\circ} 40^{\prime} 49^{\prime} \mathrm{N} \& 88^{\circ} 27^{\prime} 44^{\prime \prime} \mathrm{E} \\
21^{\circ} 38^{\prime} 47^{\prime} \mathrm{N} \& 88^{\circ} 27^{\prime} 32^{\prime \prime} \mathrm{E} \\
21^{\circ} 38^{\prime} 39^{\prime} \mathrm{N} \& 88^{\circ} 27^{\prime} 31^{\prime \prime} \mathrm{E} \mathrm{E} \\
21^{\circ} 41^{\prime} 56^{\prime} \mathrm{N} \& 88^{\circ} 26^{\prime} 04^{\prime \prime} \mathrm{E} \\
21^{\circ} 40^{\prime} 33^{\prime} \mathrm{N} \& 88^{\circ} 25^{\prime} 30^{\prime \prime} \mathrm{E} \\
21^{\circ} 40^{\prime} 18^{\prime} \mathrm{N} \& 86^{\circ} 29^{\prime \prime} \mathrm{E}\end{array}$ \\
\hline Lothian (island) & 6 & $\begin{array}{l}21^{\circ} 37^{\prime} 42^{\prime} \mathrm{N} \& 88^{\circ} 19^{\prime} 06^{\prime \prime} \mathrm{E} \\
21^{\circ} 38^{\prime} 53^{\prime} \mathrm{N} \& 88^{\circ} 18^{\prime} 47^{\prime \prime} \mathrm{E} \\
21^{\circ} 41^{\prime \prime 2} 20^{\circ} \mathrm{N} \& 88^{\circ} 18^{\circ} 48^{\prime \prime} \mathrm{E} \\
21^{\circ} 37^{\prime} 52^{\prime} \mathrm{N} \& 88^{\circ} 18^{\prime} 59^{\prime \prime} \mathrm{E} \\
21^{\circ} 42^{\prime} 20^{\prime} \mathrm{N} \& 88^{\circ} 18^{\prime} 42^{\prime \prime} \mathrm{E} \\
21^{\circ} 42^{\prime} 01^{\prime} \mathrm{N} \& 88^{\circ} 18^{\prime} 41^{\prime \prime} \mathrm{E}\end{array}$ \\
\hline Manmathanagar & 1 & $22^{\circ} 11^{\prime} 2^{\prime} \mathrm{N} \& 88^{\circ} 48^{\prime} 44^{\prime \prime} \mathrm{E}$ \\
\hline Sajnekhali & 1 & $22^{\circ} 7^{\circ} 27^{\prime} \mathrm{N} \& 88^{\circ} 49^{\prime} 48^{\prime \prime} \mathrm{E}$ \\
\hline Sudhanyakhali & 2 & $22^{\circ} 6^{\prime} 42^{\prime} \mathrm{N} \& 88^{\circ} 46^{\prime} 46^{\prime \prime} \mathrm{E}$ \\
\hline
\end{tabular}


permanganate oxidation method (Subiah and Asiza, 1956) was employed to measure available nitrogen $(\mathrm{N})$. Available phosphorus $(\mathrm{P})$ was determined using Olsen's bicarbonate extraction method (Olsen et al., 1954). Organic carbon $(\mathrm{OC})$ was quantified using wet digestion method or titrimetric method (Walkley and Black, 1934) as described by Nelson and Sommer (1982). Exchangeable potassium $(\mathrm{K})$ and sodium $(\mathrm{Na})$ were estimated using ammonium acetate extraction, followed by flame photometric method (Jackson, 1973). EDTA or versenate titration method was employed to quantify exchangeable calcium $(\mathrm{Ca})$ and magnesium $(\mathrm{Mg})$, as mentioned by Baruah and Barthakur (1997).

\section{Statistical analyses}

The data on soil parameters were subjected to one-way ANOVA to judge whether the variation in the parameters between the inundation types were significant or not. Means and standard errors were estimated for the replicate values. For all the above statistical analyses SPSS software version 11.0 was used.

\section{RESULTS}

Table 3 shows the mean values of the soil parameters at the three inundation types. Usually inundated sites had the lowest concentrations of $\mathrm{pH}$, Sal, P, K, Na and Mg; summer springtide inundated sites exhibited highest concentrations of Sal, OC, N, Na, K and Mg. Diurnally and usually springtide inundated areas exhibited the same $\mathrm{pH}$, whereas summer springtide inundated sites showed the lowest $\mathrm{pH}$. $\mathrm{P}$ and $\mathrm{N}$ did not differ significantly between the inundation types. $\mathrm{P}$ was highest and $\mathrm{N}$ lowest in the soils of the diurnally inundated sites. The cationic analysis of the soil indicated that $\mathrm{Na}$ and $\mathrm{Ca}$ ions dominated as soil salinity increased, although $\mathrm{Mg}$ and $\mathrm{K}$ concentrations were considerable under high soil salinity. Ca ion concentration was of the order diurnal $>$ usual springtide $>$ summer springtide inundated sites. 
Table 3. Mean value of each soil parameter at the three specified tidal inundation type

\begin{tabular}{|c|c|c|c|c|}
\hline \multirow[t]{2}{*}{ Soil parameters } & \multicolumn{3}{|c|}{ Inundation' } & \multirow[t]{2}{*}{$\mathrm{F}$} \\
\hline & Diurnal & Usp & Ssp & \\
\hline $\mathrm{pH}$ & $\begin{array}{l}8.04 \mathrm{~b} \\
( \pm 0.04)\end{array}$ & $\begin{array}{l}8.03 \mathrm{~b} \\
( \pm 0.03)\end{array}$ & $\begin{array}{l}7.57 \mathrm{a} \\
( \pm 0.09)\end{array}$ & $15.26 * *$ \\
\hline Salinity (ppt) & $\begin{array}{l}15.62 \mathrm{a} \\
( \pm 0.40)\end{array}$ & $\begin{array}{l}9.92 \mathrm{~b} \\
( \pm 0.40)\end{array}$ & $\begin{array}{l}21.67 \mathrm{c} \\
( \pm 1.39)\end{array}$ & $87.16^{* *}$ \\
\hline Organic carbon $(\%)$ & $\begin{array}{l}0.68 \mathrm{~b} \\
( \pm 0.05)\end{array}$ & $\begin{array}{l}0.74 b \\
( \pm 0.06)\end{array}$ & $\begin{array}{l}1.08 \mathrm{a} \\
( \pm 0.08)\end{array}$ & $6.69^{*}$ \\
\hline $\begin{array}{l}\text { Available nitrogen } \\
(\mathrm{mg} / \mathrm{kg})\end{array}$ & $\begin{array}{l}292.19 \\
( \pm 18.97)\end{array}$ & $\begin{array}{l}310.86 \\
( \pm 28.34)\end{array}$ & $\begin{array}{l}337.03 \\
( \pm 33.01)\end{array}$ & $1.54 \mathrm{~ns}$ \\
\hline $\begin{array}{l}\text { Available phosphorus } \\
(\mathrm{mg} / \mathrm{kg})\end{array}$ & $\begin{array}{l}33.92 \\
( \pm 11.42)\end{array}$ & $\begin{array}{l}18.67 \\
( \pm 1.46)\end{array}$ & $\begin{array}{l}27.36 \\
( \pm 2.78)\end{array}$ & $0.75 \mathrm{~ns}$ \\
\hline $\begin{array}{l}\text { Exchangeable potassium } \\
(\mathrm{meq} / 100 \mathrm{~g})\end{array}$ & $\begin{array}{l}2.66 \mathrm{a} \\
( \pm 0.11)\end{array}$ & $\begin{array}{l}1.95 b \\
( \pm 0.09)\end{array}$ & $\begin{array}{l}3.38 c \\
( \pm 0.37)\end{array}$ & $20.03 * *$ \\
\hline $\begin{array}{l}\text { Exchangeable sodium } \\
(\mathrm{meq} / 100 \mathrm{~g})\end{array}$ & $\begin{array}{l}27.26 \mathrm{a} \\
( \pm 0.99)\end{array}$ & $\begin{array}{l}21.97 \mathrm{~b} \\
( \pm 0.94)\end{array}$ & $\begin{array}{l}40.53 c \\
( \pm 5.38)\end{array}$ & $20.87 * *$ \\
\hline $\begin{array}{l}\text { Exchangeable calcium } \\
(\mathrm{meq} / 100 \mathrm{~g})\end{array}$ & $\begin{array}{l}19.58 \mathrm{a} \\
( \pm 1.02)\end{array}$ & $\begin{array}{l}13.79 \mathrm{~b} \\
( \pm 0.73)\end{array}$ & $\begin{array}{l}12.38 b \\
( \pm 0.99)\end{array}$ & $15.09 * *$ \\
\hline $\begin{array}{l}\text { Exchangeable magnesium } \\
\text { (meq/l00g) }\end{array}$ & $\begin{array}{l}10.58 b \\
( \pm 0.51)\end{array}$ & $\begin{array}{l}9.99 \mathrm{~b} \\
( \pm 0.55)\end{array}$ & $\begin{array}{l}14.99 \mathrm{a} \\
( \pm 1.11)\end{array}$ & $8.68^{*}$ \\
\hline
\end{tabular}

I Inundation: Diurnal - diurnally inundated sites, Usp - sites inundated by usual springtides and Ssp - sites inundated by only summer springtides, ppt-parts per thousand, meq milliequivalent. Value of $F$ from one-way ANOVA for detecting the significance of difference in the values amongst these types. Values in parentheses represent standard errors. The means followed by the same letter are not significantly different $(P=0.05)$ according to LSD. ${ }^{*} \mathrm{P}<0.05,{ }^{* *} \mathrm{P}=0.01, \mathrm{~ns}=$ not significant. 


\section{DISCUSSION}

Seawater is one of the major factors determining soil salinity and $\mathrm{pH}$ of mangrove forests (Tomlinson, 1986). Soil $\mathrm{pH}$ is an important parameter controlling the chemical status and mobility of many important elements. At high $\mathrm{pH}$, the $\mathrm{H}_{2} \mathrm{PO}_{4}$-quickly reacts with $\mathrm{Ca}$ ions to form less soluble compound tricalcium phosphate $\left[\mathrm{Ca}_{3}\left(\mathrm{PO}_{4}\right)_{2}\right]$ (Sample et al., 1980). Our study indicates that at higher $\mathrm{pH}$, concentrations of both $\mathrm{Ca}$ ions and available $\mathrm{P}$ were also high, thereby depicting a positive correlation between $\mathrm{pH}, \mathrm{Ca}$ ions and $\mathrm{P}$. The present study also reveals a positive correlation between salinity and concentrations of $\mathrm{Na}, \mathrm{Mg}$ and $\mathrm{K}$ ions, as the amount of these cations were higher under high salinity. When a soil is flooded, the concentration of oxygen is gradually reduced (Brady and Weil, 2002). When all the oxygen is consumed, $\mathrm{Mn}^{4+}, \mathrm{NO}^{3-}$ and $\mathrm{Fe}^{3+}$ are converted to $\mathrm{Mn}^{2+}, \mathrm{N}_{2}$ and $\mathrm{Fe}^{2+}$ respectively (Turner and Patrick, 1968; Patrick and Jugsujinda, 1992). In such anoxic environment inorganic $P$ which might have been previously sequestered in the insoluble $\mathrm{Fe}^{3+}$ and $\mathrm{Mn}^{4+}$ oxides/ hydroxides are partially released, resulting increase in phosphate forms (e.g., $\mathrm{PO}_{4}{ }^{3-}, \mathrm{HPO}_{4}{ }^{2-}$ and $\mathrm{H}_{2} \mathrm{PO}_{4}^{-}$) [De Laune et al., 1976; Wright et al., 2001]. This could serve as one of the possible reasons for the highest concentration of available $\mathrm{P}$ in the soils of the diurnally inundated sites. Moreover, phosphorus availability might also increase because of a decrease in biological (plant and microbial) phosphorus demand under anaerobic conditions due to flooding (Schlesinger, 1997; Mitsch and Gosselink, 2000). Amongst the cations sodium ions occur in highest concentrations in all the inundation levels. Epstein (1972) opined that excess $\mathrm{Na}^{+}$might cause nutrient deficiency by reducing the amounts of available $\mathrm{K}^{+}, \mathrm{Mg}^{2+}$ and $\mathrm{Ca}^{2+}$. In addition, $\mathrm{Na}^{+}$interferes with the function of $\mathrm{K}^{+}$as a cofactor in various reactions (Hseu and Chen, 2000). Hence sodium is a crucial factor affecting the soil properties of a mangrove marsh. Moreover, a high level of sodium ions in mangrove soils can displace ammonium ions in the cation exchange sites, resulting in their enhanced mobility (Chiu et al., 1996). This fact might be partly responsible for highest concentration of available $\mathrm{N}$ in the soils of the summer springtide inundated areas. In anaerobic soils microbial decomposition processes slow down, denitrification and volatilization losses of inorganic $\mathrm{N}$ increase (Turner and Patrick, 1968; Isirimah and Keeney, 
1973; Sexstone et al., 1985; Brady and Weil, 2002). This could be responsible for the lowest concentration of available $\mathrm{N}$ in the diurnally inundated sites. Underground water table of the Stmdarbans is shallow and enriched with high salt contents (Naskar and Guha Bakshi, 1987). During the dry season, salt molecules move along with water to the surface soil. As the water in the soil evaporates the salt molecules are left in the surface soil (Yadav et al., 1981). Since the summer springtide inundated sites receive the least number and lowest duration of tides, hence mean salinity as well as the concentrations of $\mathrm{Na}, \mathrm{K}$ and $\mathrm{Mg}$ were highest in this case. Quite high salinity and high concentrations of the estimated cations might suggest that though in the diurnally inundated sites water runs in opposite directions twice-a-day (Mandal, 2003), yet the leaching of the salt molecules are not much for these sites.

\section{ACKNOWLEDGMENT}

We thank Professor D. Roy of the Indian Statistical Institute, Kolkata for his statistical assistance. We are also thankful to the Conservator and Joint Director, Sundarbans Biosphere Reserve, and DFO, South 24-Parganas, West Bengal for the necessary permission and help they provided for the fieldwork. Lastly, we thank the field assistants for their sincere help during soil collection.

\section{REFERENCES}

BARUAH T.C. and H.P. BARTHAKUR. 1997. A textbook of soil analysis. Vikas Publishing House Pvt. Ltd. New Delhi, India. 328 pages.

BOTO K.G. 1984. Waterlogged saline soils. In: The mangrove ecosystem: research methods (S.C. Snedaker and J.G. Snedaker, eds). UNESCO, U.K. pp. 114-130.

BRADY N.C. and R.R. WEIL. 2002. The nature and properties of soil. 13th edn. Pearson Education Asia, New Delhi, India. 960 pages.

CHIU C.Y., S.C. LEE, H.T. JUANG M.T. HUR and Y.H. HWANG 1996. Nitrogen nutritional status and fate of applied nitrogen in mangrove soil. Bot. Bull. Acad. Sin. 37: 191196.

DE LAUNE R.D., W.H. PATRICK and, J.M. BRANNON. 1976. Nutrient transformations in Lousiana salt marsh soils. Sea Grant Publication, Centre for Wetland Resources, Lousiana State University, Baton Rouge, LA. 38 pages. 
EPSTEIN E. 1972. Mineral nutrition of plants principles and perspectives. Wiley, New York. 412 pages.

FOREST SURVEY OF INDIA. 1999. The State of Forest Report. Forest Survey of India, Ministry of Environment and Forests, Dehra Dun, India.

GHOSE M. 2001. Status of mangroves in Sundarbans of West Bengal, India. In: Proceedings of International Symposium on Mangrove Ecology and Biology: Mangrove ecosystems: Natural distribution, biology and management (N.R. Bhat, F.K. Taha and A.Y. Al-Nasser, eds). Kuwait Institute for Scientific Research, Kuwait.pp. 7-16.

HSEU Z.Y. and Z.S. CHEN. 2000. Monitoring the changes of redox potential, $\mathrm{pH}$ and electrical conductivity of the mangrove soils in northern Taiwan. Proceedings of National Science Council ROC. 52: 577-586.

ISIRIMAH N.O. and D.R.KEENEY. 1973. Nitrogen transformations in aerobic and waterlogged histosols. Soil Sci. 85(4): 123-129.

JACKSON M.L. 1973. Soil chemical analysis. Prentice Hall of India Private Limited, New Delhi, India. 498 pages.

MANDAL A.K. 2003. Sundarbans of India: a development analysis. Indus Publishing House, New Delhi, India. 260 pages.

MITSCH W.J. and J.G. GOSSELINK. 2000. Wetlands. 3rd edn. John Wiley \& Sons, New York. 920 pages.

NASKAR K.R. and D.N. GUHA BAKSHI. 1987. Mangrove swamps of the Sundarbans: an ecological perspective. Naya Prokash, Kolkata, India. 263 pages.

NELSON D.W. and L.E. SOMMER. 1982. Total carbon, organic carbon and organic matter. In: Methods of soil analysis, part 2,2nd edn. (A.L. Page, R.H. Milles and D.R. Keeney, eds). Amer. Soc. Agron. and Soil Sci. Soc. Amer. Inc., Madison, WI. pp. 539-579.

OLSEN S.R., C.V. COLE, F.S. WATANABE and L.A. DEAN. 1954. Estimation of available phosphorus in soils by extraction with sodium bicarbonate. U.S Department of Agriculture Circular. 939 pages.

PATRICK W.H. JR and A. JUGSUJINDA. 1992. Sequential reduction and oxidation of inorganic nitrogen, manganese, and iron in flooded soil. Soil Sci. Soc. Amer. J. 56: $1071-1073$.

SAMPLE E.C., R.J. SOPER and G.C. RACZ. 1980. Reactions of phosphate fertilizers in soils. In: The role of phosphorus in agriculture (F.E. Khasawnch, E.C. Sample and E.J. Kamprath, eds). Tennessee Valley Authority, American Society of Agronomy, Madison, WI.pp. 263-310. 
SCHLESINGER W.H. 1997. Biogeochemistry: an analysis of global change, 2 nd edn. Academic Press. New York.

SEXSTONE A.J., N.P. REVSBECH, T.N. PARKIN and J.M. TIEDJE. 1985. Direct measurement of oxygen profiles and denitrification rates in soil aggregates. Soil Sci. Soc. Amer. J. 49: 645-651.

SNEDAKER S.C. 1982. Mangrove species zonation: Why? In: Tasls for vegetation science (D.N. Sen and K.S. Rajpurohit, eds). The Hague, W. Junk. pp. 118-125.

SUBIAH B.V. and G.L. ASIZA. 1956. A rapid procedure for the estimation of available nitrogen in soils. Current Science 25: 259-261.

TOMLINSON P.B. 1994. The Botany of Mangroves, Paperback edn. Cambridge University Press, New York.

TURNER F.T. and W.H.JR. PATRICK, 1968. Chemical changes in waterlogged soils as a result of oxygen depletion. Trans. 9th Intern. Congr. Soil Sci. (Adelaide, Australia). 4:53-65.

WATSON J. 1928. Mangrove forests of the Malay Peninsula. Malayan Forest Records 6. Fraser \& Neave Limited, Singapore.

WRIGHT R.B., B.G LOCKABY and M.R. WALBRIDGE. 2001. Phosphorus availability in an artificially flooded southeastern floodplain forest soil. Soil Sci. Soc. Amer. J. 65: $1293-1302$.

YADAV J.S.P., A.K. BANDOPADHYAY, K.V.G.K. RAO, T.S. SINHA, C.R. BISWAS, B.K. BANDOPADHYAY and S.K. DUTTA. 1981. Management of coastal saline soils of Sundarbans. CSSRI-ICAR Bull. 7: 1-32. 